\title{
THE CONCEPT OF SMART HOTELS AS AN INNOVATION ON THE HOSPITALITY INDUSTRY MARKET - CASE STUDY OF PURO HOTEL IN WROCŁAW
}

\author{
DARIA ELŻBIETA JAREMEN, ${ }^{1}$ MAŁGORZATA JĘDRASIAK, ${ }^{2}$ \\ ANDRZEJ RAPACZ ${ }^{3}$
}

Uniwersytet Ekonomiczny we Wrocławiu, POLAND

${ }^{1}$ e-mail: Daria.jeremen@ue.wroc.pl

${ }^{2}$ e-mail: m.jedrasiak@hotelbaron.pl

3 e-mail: andrzej.rapacz@ue.wroc.pl

KEYWORDS | hotel, smart organization, intelligent enterprise, ICT

ABSTRACT Market observation indicates the development of a new model for running a business in hospitality industry, referred to as smart hotels. This model is specifically distinguished by the new information and communication technologies. The concept of smart hotels is relatively new and can be regarded as an innovative solution in tourism. The presented article discusses the essence of a smart hotel category and identifies the attributes of an intelligent hotel. The theoretical discussion based on the subject literature in the theory of organization and management, as well as hospitality business economics and management was also illustrated using the case study of PURO hotel in Wrocław. The necessary information was collected from both secondary and primary sources. The most important information gathering method was interpersonal in-depth interview with the aforementioned hotel's manager.

\section{Introduction}

In modern economy, the symbol which is knowledge, only these enterprises stand the chance of success which are capable of collecting, multiplying and applying this knowledge successfully. The continuously expanding capital of knowledge results in the emergence of intelligent enterprises, taking full advantage of their staff creativity. It is emphasized that smart enterprises win their market advantage owing to the application of new information and communication technologies 
(ICT), even though one should remember that technological innovations do not represent the only factor of success.

Hospitality industry represents, beyond any doubt, one of these economy sectors which take an increasingly intensive advantage of the available ICT. They play a particular role and are regarded as the key factor of intelligent (smart) hotels' effective functioning. They not only allow improved management effectiveness and higher efficiency of functioning, but also facilitate achieving such service level which, in the times of technological advancement in everyday life, can result in much batter satisfaction of the demanding guests.

The purpose of the presented article is to explain the essence of a smart hotel category and to identify the attributes distinguishing an intelligent hotel from other entities, which do not function based on this particular business model. The study takes up an attempt to present the definition of a smart hotel. In order to achieve the above-mentioned objective the review of the subject literature in the theory of organization and management, as well as hospitality business economics and management, was conducted. The theoretical discussion was illustrated using the case study of PURO hotel in Wrocław. The necessary information was collected from both secondary and primary sources, whereas the study and analysis of scientific and information providing publications constituted the data collection methods, supplemented by market observation and interpersonal in-depth interview with the aforementioned hotel's manager.

\section{The essence of smart hotels' concept}

The attempt to define a smart hotel category requires explaining the significance of the term smart and presenting the essence of economic categories created using the word smart. The discussed term, which originates from English, means clever, intelligent, ingenious and slick. Currently this term is used more and more frequently in the context of new technologies and devices, referred to as smart technologies and smart devices. The objects of everyday use become "smart objects". They are related with each other in a network, they react to changes in their environment, they continuously interact with their users (Federal Office for Information Security, 2006). If a particular device is assigned the smart attribute it means that it is easier to use, steer or program. Therefore, its functionality is better for its user. It is also more friendly and intuitive in usage. It is frequently characterized by a higher level of safety and cost effectiveness, which means that such device generates lower costs and results in higher benefits than the solutions deprived of the smart attribute.

The term smart is also used in the field of economic sciences and especially in management sciences. Initially it was associated with the development of the management by objectives concept, which emerged in the 50 s of the $20^{\text {th }}$ century. It implies high effectiveness of achieving goals on condition of defining them strictly according to the specific rules, marked by an acronym S.M.A.R.T (i.e. specific, measurable, agreed, realistic and time bound). In the $90 \mathrm{~s}$ of the $20^{\text {th }}$ century the word smart was linked with such terms as: organization and its specific case - an enterprise. Therefore such categories appeared as a smart organization (Matheson, Matheson, 1998; Afsarmanesh, Camarinha-Matos, 2000), and intelligent enterprise (Quinn, 1992). In the discussed 
concept the intelligent attribute is assigned to an enterprise the development of which is based on knowledge, its continuous multiplication, advancement and application in the process of value creation for a client.

On the grounds of economics, while analysing the essence of a smart organization, the resource-based theory of an enterprise and intellectual capital theory can be used. According to the first of them out of all available production factors it is the intellect which remains the most important resource of a company (Quinn, 1992), deciding about the efficient implementation of other resources. Similarly to above concept, in the theory of intellectual capital, people, their knowledge, involvement, entrepreneurialship and creativity are recognized as the crucial factors in creating added value and the key capital of an enterprise, which decides about the possibilities of developing and launching innovations. Thus, having in mind both of the above-mentioned theories an intelligent, smart enterprise, based on the capital of knowledge is more competitive, i.e. presents better opportunities of growth and development.

Creation, capitalization and knowledge dissemination (Brilman, 2002), also represent the attributes of the so-called "learning' organizations, hence, an intelligent enterprise is a "learning" organization. It relates its future development to the processes of ongoing improvement and upgrading qualifications, skills and competencies of all its employees. A learning enterprise constructs its potential on the grounds of five pillars (so-called P. Senge's disciplines), i.e.: personal mastery, systems thinking, mental models, shared vision and team learning (Senge, 2000).

Knowledge represents the application of information (Brilman, 2002) in company functioning. Hence, multiplying knowledge requires permanent exchange of information between company employees and also between a company and its environment. Hoping for easier access to knowledge, faster diffusion of tacit knowledge (Kowalczyk, Nogalski, 2007), an opportunity to take advantage of other's knowledge and also about others, smart enterprises frequently represent nodes in the network of cooperation systems. Multilateral cooperation relations between the network components result in numerous benefits. The causative factor takes the form of access to the accumulated potential of network members' knowledge, collective use of the available resources, as well as generating synergy effects as a result of cooperation.

Collecting information and transforming it into productive knowledge is currently supported by ICT and especially by the Internet. An intelligent enterprise is very absorptive of technical and technological advancement. Therefore, they swiftly implement modern IT solutions in their structure, systems, processes, products and services. Following the rule that success in the network economy is possible for those who take advantage of ICT processes in their companies' functioning (Grudzewski, Hejduk, 2011), both regulatory and real processes are carried out in an enterprise using Business Intelligence tools and applications, Big Data analysis processing methods, cloud and mobile solutions of business analytics, data visualization or possibilities offered by the Internet of Things. The listed solutions, on the one hand, increase the level of decision accuracy, improve the effectiveness of management, enhance the profitability of performance but, on the other, enrich positive experiences of intelligent enterprise clients. 
In the light of the above mentioned remarks it should be adapted that the idea of an intelligent enterprise is characterized by an integrated approach. An enterprise is perceived here as a knowledge-based, learning, open, networking organization, following the rule of sustainable development in its operations and also implementing at least some of its management processes in virtual space, thus taking advantage "wherever possible" of the achievements of technical and technological progress, especially in the area of information and communication technologies.

Returning to the term of a smart hotel it is worth paying attention to the fact that it is used more by practitioners than theorists. ${ }^{1}$ It is usually encountered in the subject literature and in the opinions of hospitality industry specialists. Thus, the idea of smart hotels does not stand for a theoretical concept, created as a result of scientific thought development, describing the functioning of a hotel enterprise. Instead, it is rather a practical business model which adapts new information and communication technologies in the hospitality business. In accordance with its assumptions, hotel competitiveness depends on supporting its operations by applying technological solutions. Therefore, a smart hotel category is closer to that of smart technologies than a smart organization. In the attempt to define the analysed term the standpoint of practitioners was mainly considered in the presented study and thus it was adopted that a smart hotel represents a technologically integrated system of hospitality services provision, the functioning of which is based on new information and communication technologies, either on their own or along with a small participation of a human being, responding to the signals coming from internal and external environment and adequately adjusting their activities. The attributes of such hotel are as follows: the availability of broadband Internet, the implementation of smart technologies and smart devices, effective policy aimed at the Internet and ICT dissemination and also the organizational units responsible for the implementation of new ICT (so-called technological centres) and a relatively high level of the available ICT. Smart hotels have their significant input in the research and development of knowledge related to ICT implementation in hospitality industry. They are ahead of other facilities in terms of implementing environmentally friendly systems, which facilitate the accomplishment of sustainable development goals. Smart hotels exceptionality consists in an extensive transformation of the approach towards running a hospitality business. The idea of smart hotels' construction is currently carried out in many places worldwide, in Europe and also in Poland. They emerge in response to market needs, both in terms of its demand and supply. Several well-known examples of smart hotels can be quoted here: The Upper House in Hong Kong (the guests receive iPod Touch at check-in, loaded with the set of games, music and information about the hotel for their own use); Novotel München Messe (the guests are greeted by both the real and a virtual receptionist, the hotel provides information and communication systems equipped in touchscreens, using which guests can easily find tourist information they need; Crowne Plaza in Copenhagen (owing to the application of new technologies, has become neutral in terms of $\mathrm{CO}_{2}$ emission, the entire energy used in it originates from renewable sources (e.g. bicycles propelled by the power of muscles of the guests working out

${ }^{1}$ On the grounds of tourism economics the term smart appears in the context of a tourist enterprise, whereas in the context of tourism destination as - Smart Tourism Destination (Buhalis, Amaranggana, 2013). 
in the hotel fitness $\mathrm{club}^{2}$ ), Blow Up Hall, Poznań, the hotel guests receive iPhones, instead of keys or cards, using which they enter their rooms. The above listed hotels represent the examples of an effective implementation of new information and communication technologies in their functioning. These facilities call themselves smart or are referred to as such by their environment.

\section{Information-Communication technology ICT in hotel industry}

According to G. Weigel (2004) ICT means the entire spectrum of technologies designed to access, process and transmit information in relation to text, sound, data and pictures. ICT covers the whole range from traditional, widely used devices such as radios, telephones or television to more sophisticated tools like computers or the Internet and merges information technology with communication technology. ICT encompasses any medium to record information (magnetic disk/tape, optical disks - DVD/CD, flash memory and arguably also paper records), technology for broadcasting information (radio, television) and technology for communicating through voice, sound and pictures (microphone, camera, loudspeaker, telephone and cellular phones) (Januszewska, Jaremen, Nawrocka, 2015). ICT have been transforming tourism globally (Buhalis, Law, 2008).

Table 1. Components of ICT according to the four hotel operational domains

\begin{tabular}{ll}
\hline \multicolumn{1}{c}{ ICTs Group } & \multicolumn{1}{c}{ Components of ICTs Group } \\
\hline & $\begin{array}{l}\text { Building automation systems/Building management system; Property management system; } \\
\text { Convent management system; Marketing and sales system; Management and decision support } \\
\text { system; Human resource management system; Purchasing system; Financial and accounting } \\
\text { system; Decision support system ; Wireless internet connection area; Customer relationship } \\
\text { management system; Security system; Business center; Generating report and update statistics } \\
\text { system; Teleconference system; ATM (the cash access automatic teller machine) }\end{array}$ \\
& $\begin{array}{l}\text { Telephone and fax systems; Web site and e-mail systems; Global distribution system; Guest } \\
\text { account management system; Check-in/check-out system; Central reservation system; Room }\end{array}$ \\
\hline \multirow{2}{*}{ Room division ICTs } & status and housekeeping management system; Customer database system; Statistic and report \\
\& hont office desk & system \\
\hline Food and beverage (F\&B) division & $\begin{array}{l}\text { Electronic point of sale system; Stock and inventory systems; Conference and banqueting } \\
\text { system; Menu management system; Table reservation system; Order entry systems; Sales and } \\
\text { ICTs }\end{array}$ \\
\hline & $\begin{array}{l}\text { In-room telephone system; Electronic locking system; Energy management systems; Automated } \\
\text { wake-up system; Voice mail system; In-room internet access line/wireless; In-room entertain- }\end{array}$ \\
\hline In-room ICTs & ment system; In-room electronic safety boxes \\
\hline
\end{tabular}

Source: authors' compilation based on: Sirirak, Islam, Khang (2011); Siguaw, Enz, Namasivayam (2000); Sigala (2003); Law, Jogaratnam (2005); Prakash (2007).

In hotel industry the result of implementation of ICT is higher efficiency of the guests' experiences generating process. ICT gives a wide range of tools to improvement of the service quality and the customer satisfaction. So they have become fundamental elements of value generating strategies in the

\footnotetext{
${ }^{2}$ One hotel guest riding a bike at an average speed of $30 \mathrm{~km} / \mathrm{h}$ is able to produce about 100 watt hours of electric power in 60 minutes.
} 
hotel industry (Gretzel, 2011). ICT supports also process of automation of operations and self-service in the hotels, resulting in reduction of production and distribution costs. ICT uses in the accommodation sector are varied, and the extent to which ICT is used and the form of its application are linked to the type of accommodation provider (luxury hotel, budget hotel, B\&B etc.), the segment of guests, the size of the operation, its ownership and its location. Hotel ICTs are predominantly categorized into four groups (Table 1).

\section{ICT application by Purpo hotel in the light of empirical research}

As it has already been mentioned, case study research method was used in the course of the research process for the purposes of the presented study. The process of case study formation was divided into steps, in which each consecutive phase should result from the previous one. The most important step was collecting information for the purposes of case study development. Since the quality of gathered materials has impact on the conclusions. The answers were investigated not only during a direct interview with the hotel manager, but also based on the analysis of data collected from different sources, such as: direct observations, press releases and the content of the Internet portals. The description constituted the basic technique for analysing the collected empirical materials. The main source of information takes the form of a personal interview. The basic objective of the conducted research was to present the practical dimension of a smart hotel concept based on Puro Hotels group. Two research questions were put forward:

1. What are the characteristics of a smart hotel which decide about its distinctiveness on the hotel market?

2. What are the determinants of ICT application in a hotel as well as the resulting advantages?

In Poland there are about 300 hotels, mainly four- and five star ones, which can be referred to as leaders in terms of applying innovative technological solutions in hospitality business (Wind Mobile, 2015). One of them is the chain of Puro Hotels. It was originated by Genfer Hotels company owned by a Norwegian group Genfer operating in the shipbuilding sector and real-estate trading. The investor's idea was to establish a chain of smart hotels in which, as a result of ICT technology and self-service system application, the time of customer service will be maximally shortened, along with ensuring a favourable quality - price ratio. Currently, the chain of Puro hotels owns four, $3 *-4 *$ facilities: in Wrocław, Cracow, Poznań and Gdańsk. The construction of the first smart Puro hotel was initiated in 2010 in Wrocław. Fifteen months later a five-storey building was opened offering 102 rooms. Its name comes from Spanish. The word "puro" - "pure" - is supposed to symbolize simple solutions and the application of self-service system for its guests (PWS ProMedia, 2011). The offer of Puro chain is mainly addressed to the younger generation of clients, brought up in the "era" of the Internet and social media. It was already at the facility designing stage when the investors asked the Internet users to provide them with guidelines helpful in developing a hotel designed in accordance with the guests' expectations. The potential clients could report their requirements and preferences at the hotel profile on Facebook, later used in the course of Puro hotels construction. Following such comments the chain of Puro hotels implemented innovative solutions 
and ICT applications in each of the hotel units. The implemented technologies had to meet three basic conditions: firstly, to be safe for both the hotel guests and its staff; secondly, to have properly functioning communication and to be integrated with BAS/BMS systems (Building Automation Systems/Building Management Systems - computer integrated systems for managing building, steering, controlling and reporting the condition and changes of all facility components, such as e.g. heating, ventilation, fire protection, alarm, monitoring system, etc.) and thirdly, present high functionality level - the systems cannot remain just an attraction, but primarily are supposed to serve both hotel guests and staff in order to meet their needs at a high level. By means of using adequate ICT tools a hotel offers unique solutions in terms of automation systems and buildings' management consisting in the integration of: monitoring and lightening control of the building, hotel sound system, heating, air-conditioning and ventilation, visualisation of alarm situations, remote steering and monitoring via the Internet, managing integrated installations in the building.

CMS (Content Management Systems) and PMS (Property Management Software) have also been integrated in the hotel. The first refers to content management, i.e. its flexible forming and presenting on websites, as well as other computer systems requiring communication with a user. It allows those professionally unprepared to put content into such services and systems and receive a response to the introduced changes. CMS is used in Puro hotel to manage the content of devices available to guests (e.g. tablets). Based on the system guests can adjust all parameters affecting their comfortable stay in a hotel using just one interface. It also provides for the two-way communication between the hotel guests and its staff, allowing information viewing about an object and sending them to the front office, internal telephone calls, self-check-out, as well as ordering services (e.g. cleaning, room service).

Property Management Software (PMS) - the second of the computer management systems distinguished by Puro hotel represents the set of integrated software which have direct impact on the functioning of many hotel departments, e.g.: accounting (account management, income management), sales and front desk (booking management, customer base management), marketing (price management, customer base management), front desk and housekeeping (guest room management). PMS system is also capable of communicating with other systems, e.g. access control system (hotel locks), PBX system (telephone exchange), food and beverage systems, conference and banqueting service systems, fiscal systems, Spa \& wellness systems, financial and accounting software, BAS/BMS systems and hotel TV systems (Głowa, 2011). Puro hotel offers one of the most advanced models of hotel TV systems with the built-in AllShare network solution, ensuring easy and intuitive connection of mobile devices owned by the guests, such as: smartphones, tablets or notebooks and displaying their content on a big screen.

The implementation of the above described ICT solutions in the Puro hotel located in Wrocław would not be possible without the cooperation with High-Tech sector companies, e.g. with: Samsung Electronics Poland, Procom Systems, Software Mind and kkvlab.

Among the major advantages resulting from ICT application in Puro hotel its manager Ł. Piekarski listed the following:

- automation of the majority of hotel procedures (e.g. check-in, check-out), 
- reduced number of staff (in case of standard solutions a hotel offering 102 rooms would have to employ about 40 workers, Puro hotel in Poznań employs only 16, employment rate per room $=0,16$ ),

- lower operating costs,

- shortened service realization time - online booking with the text message system (after booking confirmation the guest receives a text message with the basic data about the booking made),

- reduced risk of making mistakes,

- higher customer satisfaction,

- higher efficiency and easier internal communication of staff,

- automation of documents and information circulation (SharePoint Online program) and data archivization,

- management board concentration on continuous improvement of the carried out activities, rather than the operating ones,

- upgraded room standard,

- lower room price - resulting from energy savings and employment reduction the price in Puro Hotel is comparatively lower than the price in the same category hotels.

As R. Askevoldm, the executive director of CEO Puro Hotels, mentioned in one of the interviews "The company philosophy allowed creating a new business model in hospitality business, which provides very good conditions of resting for an affordable price as a result of concentrating on the issues most important for the guests, along with the awareness that the higher automation of solutions, the lower the hotel functioning costs and in consequence lower price of the hotel service offered" (Nowoczesna Firma, 2010).

ICT implementation in Puro hotel operating and strategic activities would not be possible without all the competencies and knowledge of its staff about the new technologies and opportunities they offer in the area of better efficiency of the performed tasks. The staff of the analysed facility is characterized by high working capacity and skills in using high-tech tools supporting the provision of services. ICT implementation in Puro hotel functioning also results from the creativity and entrepreneurship of its managers. All these solutions are used to follow the global trends on the hotel market, meet customer needs and reduce costs (Wolna-Samulak, 2012).

The strategy of processes automation and controlling operations using computer systems, as well as their consistent implementation adopted in the analysed enterprise resulted in Puro hotel being currently recognized not only as the leader in high-tech sector, but also in terms of prices and customer service quality. It was reflected in many awards granted to the analysed hotel. In 2011 it was awarded the statuette - Construction of the Year 2011 (RE-Bau, 2012). In 2012 it was nominated for the prestigious European Hotel Design Award in the category "The best newbuilt hotel" (Hotelinfo24.pl, 2011) and took the second place as the most beautiful public utility building in the $12^{\text {th }}$ edition of the competition Beautiful Wrockaw (www.wroclaw.pl, 2015), moreover, it was distinguished as the Top Hotel Debut (Rydlewska, 2014). A year later it received the main prize Top Hotel 2013. In the third edition of the Hotel of the Year plebiscite, held in 2014 and organized by the HRS 
booking portal, Newsweek weekly and Forbes magazine, Puro Hotel won in the category 'chain of the year' for the unique, on Polish market, concept of self-service hotels (HRS Poland, 2014).

In the interview carried out for the purposes of the presented study the manager of Wrockaw facility additionally emphasized that the new trend of smart hotels, initiated in Poland by the Puro group, will be subject to ongoing improvement, modernization and development.

\section{Conclusions}

The problems related to smart hotels' functioning have been receiving an increasing coverage in the subject literature, with the main focus on ICT application in hospitality industry. So far the concept of smart hotels has been functioning primarily as a practical formula for running a hospitality business, which has not yet received any in-depth scientific description or the commonly adopted definition. In its practical aspect, the application of ICT in operating and strategic activities of a hotel is recognized as the fundamental attribute of smart hotels.

The results of studies carried out for the purposes of the presented article's goal realization provide grounds to conclude that: ICT application in Puro hotel results in measurable advantages for both an enterprise and its clients. For this reason the new technologies are implemented wherever possible and used in all functional areas. The proper functioning of ICT tools in a hotel and the resulting advantages maximization require the integration of ICT technologies implemented in an enterprise, whereas the development of BAS/BMS or PMS systems allows such integration to a larger extent.

The usage of smart technologies in hotel helps to be a smart organisation. The analysis of ICT implementation advantages in hotel Puro shows the significant impact of ICT on its business model. The components of such business model are:

- a main target of enterprise is to maximize profit by the use ICT,

- a key resource of enterprise is the personnel equipped with ICT for gathering information/ increase knowledge and efficiently performing their tasks,

- a meaningful share of ICT in creating value for the customer.

The smart organization idea implementation in hotels' functioning has positive impact on their image and distinguishes them from their competitors, which is confirmed by the media interest in Puro hotel and its numerous awards received in various competitions.

The results of research allow to confirm that the concept of smart hotel is not only a marketing trick. It is a new business model in hotel industry.

\section{References}

Afsarmanesh, H., Camarinha-Matos, A.M. (2000). Future Smart-Organizations: A Virtual Tourism Enterprise. In: Proceedings of the First International Conference on Web Information Systems Engineering (pp. 1, 456-461). Hong Kong: IEEE Explore.

Brilman, J. (2002). Nowoczesne koncepcje i metody zarzadzania. Warsaw: PWE.

Buhalis, D., Amaranggana, A. (2013). Smart tourism destinations. In: Z. Xiang, I. Tussyadiah (eds.), Information and communication technologies in tourism 2014 (pp. 553-564). Switzerland: Springer International Publishing. 
Buhalis, D., Law, R. (2008). Progress in information technology and tourism management: 20 years on and 10 years after the Internet - The state of eTourism research. Tourism Management, 29 (4), 609-623.

Federal Office for Information Security (2006). Pervasive Computing: Trends and Impacts, Bonn-Ingelheim: BSI SecuMedia Verlags-GmbH.

Głowa, A. (2011). PMS: system hotelowy. Available at: www.abchotelu.pl (20.02.2016).

Gretzel, U. (2011). Intelligent systems in tourism: A social science perspective. Annals of Tourism Research, 38 (3), 757-779.

Grudzewski, W.M., Hejduk, I.K. (2011). Przedsiębiorstwo przyszłości. Zmiany paradygmatów zarządzania. Master of Business Administration, 1 (116), 95-111.

Hotelinfo24.pl (2011). Wrocławski Hotel Puro wyróżniony w European Hotel Design Awards. Available at: http://www. hotelinfo24.pl (12.02.2016).

HRS Poland (2014). Sieć roku. Available at: http://2014.hotelroku.com (13.02.2016).

Januszewska, M., Jaremen, D.E., Nawrocka, E. (2015). The effects of the use of ICT by tourism enterprises. Szczecin University Scientific Journal, Service Management, 16 (2), 65-73.

Kowalczyk, A., Nogalski, B. (2007). Zarządzanie wiedza. Koncepcja i narzędzia. Warsaw: Difin.

Law, R., Jogaratnam, G. (2005). A study of hotel information technology applications. International Journal of Contemporary Hospitality Management, 17 (2), 170-180.

Matheson, D., Matheson, J.E. (1998). The Smart Organization: Creating Value Through Strategic R\&D. BostonMassachusetts: Harvard Business School Press.

Nowoczesna Firma (2010). Sieć Puro Hotel wkracza do Polski. Available at: http://nf.pl (19.12.2015).

Piękny Wrocław (2015). Available at: www.wroclaw.pl (12.02.2016).

Prakash, K.C. (2007). The impact of information technology on hotel operations, service management and transaction costs: a conceptual framework for full-service hotel firms. International Journal of Hospitality Management, 26 (2), 395-408.

PWS ProMedia (2011). Wrocław: pierwszy PURO Hotel, Hotelarz, 4, 4.

Quinn, J.B. (1992). Intelligent enterprise: A knowledge and service based paradigm for Industry. New York: Free Press.

RE-Bau (2012). Budowa Roku 2011. Available at: http://www.re-bau.com (12.02.2016).

Rydlewska, H. (2012). Samotność w hotelu, czyli najmodniejszy nocleg we Wrocławiu. Available at: http://natemat.pl (12.02.2016).

Senge, P.M. (2000). Piąta dyscyplina. Teoria i praktyka organizacji uczacych się. Warsaw: ABC.

Sigala, M. (2003). The ICTs productivity impact on the UK hotel sector. International Journal of Operations \& Production Management, 23 (10), 12241245.

Siguaw, A., Enz, A., Namasivayam, K. (2000). Adoption of information technology in US hotels: strategically driven objectives. Journal of Travel Research, 39 (2), 192-201.

Sirirak, S., Islam, N., Khang, D.B. (2011). Does ICT hotel adoption enhance hotel performance. Journal of Hospitality and Tourism Technology, 2 (1), 34-49.

Weigel, G. (2004). ICT4D Today - enhancing knowledge and people-centred communication for development and poverty reduction. In: G. Weigel, D. Waldburger (eds.), ICT4D - connecting people for a better world. Lessons, Innovations and Perspectives of Information and Communication Technologies in Development (pp. 15-42). Berne: SDC-GKP.

Wind Mobile (2015). Kolejne wdrożenie iLumio dla sieci PURO Hotels. Available at: https://infowire.pl (12.02.2016).

Wolna-Samulak, A. (2012). Innowacje w zarządzaniu organizacją na przykładzie hotelu PURO we Wrocławiu. Współczesne Problemy Ekonomiczne, 5, 185-168. 


\section{KONCEPCJA SMART HOTELI JAKO INNOWACJA NA RYNKU HOTELARSKIM - STUDIUM PRZYPADKU HOTELU PURO WE WROCŁAWIU}

\section{SŁOWA KLUCZOWE \\ STRESZCZENIE}

hotel, smart organization, inteligentne przedsiębiorstwo, ICT

Obserwacja rynku wskazuje na rozwój nowego modelu prowadzenia biznesu w hotelarstwie, znanego pod nazwą smart hoteli (hoteli inteligentnych). Wyróżnikiem tego modelu jest zastosowanie w działalności nowoczesnych technologii informacyjno-komunikacyjnych. Koncepcja smart hoteli jest stosunkowo nowa i może być uznana za innowacyjne rozwiązanie w turystyce. Celem prezentowanego artykułu jest wyjaśnienie istoty kategorii smart hotelu i wskazanie na jego atrybuty. Rozważania teoretyczne prowadzone w oparciu o piśmiennictwo z zakresu teorii organizacji i zarządzania, a także ekonomiki i zarządzania hotelarstwem, zilustrowano również studium przypadku wrocławskiego hotelu PURO. Niezbędne informacje pozyskano zarówno ze źródeł wtórnych, jak i pierwotnych. Najistotniejsza metodą gromadzenia informacji był interpersonalny wywiad pogłębiony z menedżerem wspomnianego hotelu. 